\title{
Comparison of the effectiveness of dipping agents on bacteria causing mastitis in cattle
}

\author{
Krzysztof Skowron ${ }^{1, A-F}$, Alicja Sękowska, ${ }^{1, B, D-E}$, Agnieszka Kaczmarek ${ }^{1, B-C, E}$, \\ Katarzyna Grudlewska, ${ }^{1, B-C, E}$, Anna Budzyńska, ${ }^{1, B, E}$, Agata Białucha ${ }^{1, B, E}$, \\ Eugenia Gospodarek-Komkowska, ${ }^{1, F}$ \\ ${ }^{1}$ Department of Microbiology, Nicolaus Copernicus University, Toruń, Poland; Collegium Medicum of L. Rydygier, \\ Bydgoszcz, Poland \\ A - Research concept and design, B - Collection and/or assembly of data, C - Data analysis and interpretation, \\ $D$ - Writing the article, E - Critical revision of the article, F - Final approval of article
}

\begin{abstract}
Skowron K, Sękowska A, Kaczmarek A, Grudlewska K, Budzyńska A, Białucha A, Gospodarek-Komkowska E. Comparison of the effectiveness of dipping agents on bacteria causing mastitis in cattle. Ann Agric Environ Med. 2019; 26(1): 39-45. doi: 10.26444/aaem/82626
\end{abstract}

\begin{abstract}
Introduction. Mastitis may result in physical, chemical and microbiological changes in milk and pathological lesions in the glandular tissue. Milk derived from cows with mastitis may become a cause of infections in humansw and animals.

Objectives. The aim of this study was to assess the effectiveness of selected dipping agents in the inactivation of several bacteria that may cause mastitis in cattle.

Materials and method. Three strains of each of the following species: Escherichia coli, Klebsiella pneumoniae, Serratia marcescens, Staphylococcus aureus and Listeria monocytogenes, isolated from milk, were used in the study. Identification of isolates was carried out using the automatic system VITEK2 Compact. Evaluation of the genetic similarity between the tested strains was made using the RAPD technique. Drug susceptibility of strains was evaluated with the disc diffusion method. Assessment of the effectiveness of iodine, stabilized iodine, povidone iodine and chlorhexidine was performed using fragments of skin from cow teats.

Results. All the tested strains were genetically different. Most of them were susceptible to the studied antibiotics. Only two strains of $L$. monocytogenes were resistant to all the studied antibiotics. The percentage rate of reduction in the number of bacteria after using of dipping agents was very high (>90\%). The most susceptible to the dipping preparations used were L. monocytogenes (99.6 - 99.9\%). Stabilized iodine was the most effective dipping agent for all tested bacteria, causing a reduction rate in the number of bacteria from $99.80 \%$ (E. coli) - 99.99\% (S. aureus, L. monocytogenes).

Conclusions. The results obtained may contribute to a reduction in udder infections in cows, especially mastitis, and improve the quality of the milk.
\end{abstract}

\section{Key words}

Mastitis, dipping agents, bacteria inactivation, udder

\section{INTRODUCTION}

Inflammation of the mammary gland (mastitis) may affect different animal species. Mastitis is currently one of the major problems of dairy industry [1], usually caused by bacterial infection. In dairy cows this disease occurs in a clinical or subclinical form [2]. The consumption of unpasteurized milk or its products is especially dangerous and there is evidence that microorganisms derived from raw milk (especially Campylobacter jejuni and Staphylococcus auresus) may cause outbreaks among humans. An additional risk may be the possibility of spreading via milk drug-resistant strains from cows with mastitis. Microbiologically contaminated milk poses a threat not only to consumers but also to service workers and the other animals in herd $[3,4]$. Pathogenic strains may get into milk directly, as a result of their presence in milk from an infected animal and indirectly from the environment. Transmission of microorganisms between animals from one herd occurs through milking machines, udder hygiene preparations and the staff dairy employed [5].

Address for correspondence: Krzysztof Skowron, Department of Microbiology, Nicolaus Copernicus University in Toruń, Collegium Medicum of L. Rydygier in Bydgoszcz, M. Skłodowskiej-Curie 9, 85-094 Bydgoszcz, Poland e-mail: skowron238@wp.pl

Received: 14.06.2017; accepted: 11.01.2018; first published: 21.02.2018
S. aureus is the most common etiological agent of mastitis $[1,6,7]$. In Sweden, Germany and Poland, the frequency of S. aureus in cows with the clinical form of mastitis is $28.4 \%$, $10.0 \%$ and $8.6 \%$, respectively $[8,9,10]$. Escherichia coli is also responsible for many acute clinical cases of mastitis, referred to as 'colimastitis' [11]. n the Sweden and Germany, coli is the cause of $34.7 \%, 21.9 \%$ and $10.2 \%$ of clinical cases of mastitis in cows, respectively $[8,9,12]$. Ruminants are the natural reservoir of verotoxin-producing Escherichia coli (VTEC) responsible for, e.g. haemolytic-uraemic syndrome and haemorrhagic colitis [13].

Klebsiella pneumoniae and Serratia marcescens are rarely isolated from cases of mastitis; however, infections caused by these bacteria are difficult to treat [14]. In Poland and in Japan, the incidence of $S$. marcescens in cows with mastitis is $3.1 \%$ and $4.7 \%$, respectively $[10,15]$.

Listeria monocytogenes cause listeriosis in humans and various animal species [16]. Udder infection with L. monocytogenes is most commonly reported in sheep and goats. L. monocytogenes bovine mastitis is less commonly reported while sub-clinical mastitis in cows can remain undetected $[17,18]$.

The most commonly used dipping agents include preparations with iodine and its derivatives and with chlorhexidine [19]. Predipping and postdipping is aimed 
at destroying microorganisms which can be found on the skin of cows and in a drop of milk lying in the teat canal [2]. Iodine disinfects quickly and shows a wide spectrum of activity. Iodophors are iodine compounds with a water soluble polymer and slowly release iodine while at the same time decreasing its toxicity [20]. Chlorhexidine remains on the skin and shows antibacterial effect for a long time. Other active substances used in preparations are derivatives of dodecylsulfate acid, organic acids and quaternary ammonium bases [21].

The risk of infection to humans and animals is greatly reduced by pasteurization of the milk, but is not designed to sterilize it. The microbiological quality of pasteurized milk is dependent on the natural microflora of raw milk, the processing conditions and post-heat treatment contamination [22]. Microbiological analysis of pasteurized milk indicated the presence of pathogens, such as Staphylococcus aureus, Salmonella sp. and Escherichia coli $[23,24]$. Bacterial infection affects the milk quality, and with it the opportunity to produce high quality dairy products.

The presented study is the first to compare the effectiveness of dipping agents on udder skin contaminated by strains from different species.

\section{OBJECTIVE}

The aim of this study was to compare the effectiveness of some dipping agents in the inactivation of selected bacteria causing mastitis in cattle.

\section{MATERIALS AND METHOD}

Research material. Three strains of each species (E. coli, K. pneumoniae, S. marcescens, S. aureus and L. monocytogenes) isolated from milk samples from cows were used in the study, isolated form one dairy cattle herd in March 2014. Identification of isolates was carried out using the automatic system VITEK2 Compact (bioMérieux). Evaluation of the genetic similarity between the tested strains was performed using the RAPD technique (Tab. 1) [25, 26, 27]. To determine the degree of genetic similarity between the isolates, phylogenetic dendrograms were create in the CLIQS 1D Pro software (TotalLab). Clustering analysis was carried out by hierarchical grouping using the UPGMA technique with the Dice factor.

Evaluation of drug susceptibility. Drug susceptibility of strains was evaluated with the disk diffusion method on MuellerHinton Agar medium (Biocorp), and for L. monocytogenes strains on the same medium enriched with $5 \%$ of defibrinated horse blood and $20 \mathrm{mg} / \mathrm{L}$ NAD (Biocorp). The control included reference strains of $E$. coli ATCC 25922, S. aureus ATCC 29213 and Streptococcus pneumoniae ATCC 49619 from the American Collection of Reference Strains. Antibiotics were selected based on the current guidelines of EUCAST v. 6.0 and their use in veterinary medicine. The antibiotics used were: cefuroxime $(30 \mu \mathrm{g})$, gentamicin $(10 \mu \mathrm{g})$, amikacin $(30 \mu \mathrm{g})$, netilmicin $(10 \mu \mathrm{g})$, tobramycin $(10 \mu \mathrm{g})$, ciprofloxacin $(5 \mu \mathrm{g})$, ofloxacin $(5 \mu \mathrm{g})$, co-trimoxazole $(1,25-23,75 \mu \mathrm{g})$, tigecycline $(15 \mu \mathrm{g})$, erythromycin $(15 \mu \mathrm{g})$, clindamycin $(2 \mu \mathrm{g})$, penicillin $(1 \mu \mathrm{g})$, ampicillin $(2 \mu \mathrm{g})$ and meropenem $(10 \mu \mathrm{g})$.

Table 1. Sequences of primers used, composition of reactive mixtures and reaction conditions

\begin{tabular}{|c|c|c|c|c|}
\hline Microorganism & Starter sequence & Reactive mixture composition & Reaction conditions & References \\
\hline Escherichia coli & $\begin{array}{l}\text { M13-core primer } \\
\text { (5'-GAG GGT GGC GGT TCT-3,) }\end{array}$ & \multirow{3}{*}{$\begin{array}{l}25 \mu \mathrm{l}: \\
1 \times \mathrm{PCR} \text { buffer with } 2 \mathrm{mM} \mathrm{MgCl} \text { (Promega), } \\
\left.1 \mathrm{mM} \mathrm{MgCl}{ }_{2} \mathrm{ABO}\right), \\
15 \mu \mathrm{M} \text { dNTPs (Promega), } \\
1 \mu \mathrm{M} \text { primer (Oligo.pl), } \\
2.5 \mathrm{U} \text { Taq DNA polymerase (Promega), } \\
\text { ultrapure water (Sigma-Aldrich) } \\
3 \mu \mathrm{I} \text { DNA }\end{array}$} & $\begin{array}{l}\text { Denaturation: } 5 \mathrm{~min} . \text { at } 94^{\circ} \mathrm{C} \text {. } \\
40 \text { cycles: } 1 \mathrm{~min} \text {. at } 94^{\circ} \mathrm{C} ; 1 \mathrm{~min} . . \text { at } 47^{\circ} \mathrm{C} ; 1 \\
\text { min.. at } 72^{\circ} \mathrm{C} \text {. } \\
\text { Final elongation: } 8 \min . . \text { at } 72^{\circ} \mathrm{C} \text {. }\end{array}$ & $\begin{array}{l}\text { Vogel et al., } \\
2000 . \\
\text { Author's } \\
\text { modification }\end{array}$ \\
\hline $\begin{array}{l}\text { Klebsiella } \\
\text { pneumoniae }\end{array}$ & $\begin{array}{l}\text { ERIC-1 } \\
\left(5^{\prime} \text {-ATGTAAGCTCCTGGGGATTCAC-3') }\right.\end{array}$ & & $\begin{array}{l}\text { Denaturation: } 2 \text { min. at } 94^{\circ} \mathrm{C} \text {. } \\
35 \text { cycles: } 1 \mathrm{~min} \text {. at } 94^{\circ} \mathrm{C} ; 1 \mathrm{~min} \text {. at } 25^{\circ} \mathrm{C} ; 4 \\
\text { min. at } 72^{\circ} \mathrm{C} \text {. } \\
1 \text { cycle: } 1 \mathrm{~min} \text {. at } 94^{\circ} \mathrm{C} .1 ; \min \text {. at } 25^{\circ} \mathrm{C} ; 8 \mathrm{~min} \text {. } \\
\text { at } 72^{\circ} \mathrm{C} \text {. }\end{array}$ & $\begin{array}{l}\text { Vogel et al., } \\
1999 . \\
\text { Author's } \\
\text { modification }\end{array}$ \\
\hline $\begin{array}{l}\text { Seratia } \\
\text { marcescens }\end{array}$ & $\begin{array}{l}\text { ERIC- } \\
\text { 2/1026 } \\
\text { (5'-AAGTAAGTGACTGGGGTGAGCG-3'/ } \\
\text { 5'-TACATTCGAGGACCCCTAAGTG-3') }\end{array}$ & & $\begin{array}{l}2 \text { cycles: } 5 \mathrm{~min} \text {. at } 94^{\circ} \mathrm{C} ; 5 \mathrm{~min} \text {. at } 35^{\circ} \mathrm{C} ; 5 \mathrm{~min} \text {. } \\
\text { at } 72^{\circ} \mathrm{C} \text {. } \\
31 \text { cycles: } 1 \mathrm{~min} \text {. at } 94^{\circ} \mathrm{C} ; 1 \mathrm{~min} \text {. at } 50^{\circ} \mathrm{C} ; 2 \\
\text { min. at } 72^{\circ} \mathrm{C} \text {. } \\
\text { Final elongation: } 8 \mathrm{~min} \text {. at } 72^{\circ} \mathrm{C} \text {. }\end{array}$ & $\begin{array}{l}\text { Vogel et al., } \\
1999 . \\
\text { Author's } \\
\text { modification }\end{array}$ \\
\hline $\begin{array}{l}\text { Staphylococcus } \\
\text { aureus }\end{array}$ & $\begin{array}{l}\text { OLP6 } \\
\left(5^{\prime}-\text { GAGGGAAGAG-3') }\right.\end{array}$ & $\begin{array}{l}25 \mu \mathrm{l}: \\
1 \times \mathrm{PCR} \text { buffer with } 2 \mathrm{mM} \mathrm{MgCl}{ }_{2} \text { (Promega), } \\
1 \mathrm{mM} \mathrm{MgCl}(\mathrm{ABO}), \\
20 \mu \mathrm{M} \mathrm{dNTPs} \text { (Promega), } \\
2 \mu \mathrm{M} \text { primer (Oligo.pl), } \\
\text { 3.5 U Taq DNA polymerase (Promega), } \\
\text { ultrapure water (Sigma-Aldrich) } \\
3 \mu \mathrm{INA}\end{array}$ & $\begin{array}{l}\text { Denaturation: } 94^{\circ} \mathrm{C} \text { for } 5 \mathrm{~min} \text {. } \\
40 \text { cycles: } 1 \text { min. at } 93^{\circ} \mathrm{C} ; 1.5 \mathrm{~min} \text {. at } 37^{\circ} \mathrm{C} ; 1 \\
\text { min. at } 72^{\circ} \mathrm{C} \text {. } \\
\text { Final elongation: } 8 \text { min. at } 72^{\circ} \mathrm{C} \text {. }\end{array}$ & $\begin{array}{l}\text { Reinoso et al., } \\
2004 . \\
\text { Author's } \\
\text { modification }\end{array}$ \\
\hline $\begin{array}{l}\text { Listeria } \\
\text { monocytogenes }\end{array}$ & $\begin{array}{l}\text { OPA-11 } \\
\left(5^{\prime}-\text { CA AT CG CC GT-3') }\right.\end{array}$ & $\begin{array}{l}25 \mu \mathrm{l}: \\
1 \times \mathrm{PCR} \text { buffer with } 2 \mathrm{mM} \mathrm{MgCl}_{2} \text { (Promega), } \\
\left.1.5 \mathrm{mM} \mathrm{MgCl}{ }_{2} \mathrm{ABO}\right) \\
20 \mu \mathrm{M} \text { dNTPs (Promega), } \\
1 \mu \mathrm{M} \text { primer OPA-11 (Oligo.pl), } \\
1.25 \mathrm{U} \text { Taq DNA polymerase (Promega), } \\
\text { ultrapure water (Sigma-Aldrich) } \\
3 \mu \mathrm{DNA}\end{array}$ & $\begin{array}{l}6 \text { cycles: } 1 \mathrm{~min} \text {. at } 94^{\circ} \mathrm{C} ; 2 \mathrm{~min} \text {. at } 30^{\circ} \mathrm{C} ; 1 \mathrm{~min} \text {. } \\
\text { at } 72^{\circ} \mathrm{C} \text {. } \\
35 \text { cycles: } 15 \mathrm{sec} \text { at } 94^{\circ} \mathrm{C} ; 1 \mathrm{~min} \text {. at } 37^{\circ} \mathrm{C} ; 45 \\
\text { sec. at } 72^{\circ} \mathrm{C} \text {. } \\
\text { Final elongation: } 10 \mathrm{~min} \text { at } 72^{\circ} \mathrm{C} \text {. }\end{array}$ & $\begin{array}{l}\text { Ozeby et al., } \\
2006 . \\
\text { Author's } \\
\text { modification }\end{array}$ \\
\hline
\end{tabular}


Evaluation of effectiveness of dipping agents. The tested dipping agents were commercially available iodine, stabilized iodine (ethanolic solution of iodine stabilized in potassium iodide), povidone iodine (PVP) (10\% polyvinylpyrrolidone) and chlorhexidine,. Preparations were applied in the working concentration specified by the producer. Fragments of teat skin $(1 \times 1 \mathrm{~cm})$ were submerged in suspensions of all the examined strains (0.5 McFarland standards) (one in each strain) and left to dry. The skin fragments contaminated with each suspension were then submerged in all the examined dipping agents (one in each agent for $10 \mathrm{~s}$, than placed on sterile plate and left for $20 \mathrm{~m}$. This time simulated the remaining of a dipping agents on the udder skin. They were then shaken for $2 \mathrm{~min}$ at $400 \mathrm{rpm}$ in the neutralizing medium (tween 80 - 10.0 g; lecithin - 1.0 g; histidine $\mathrm{L}-0.5 \mathrm{~g} ; \mathrm{Na}_{2} \mathrm{~S}_{2} \mathrm{O}_{3}$ $-2.5 \mathrm{~g}$; water $-1000 \mathrm{ml}$ ) and subjected to sonication $(20 \mathrm{~min})$.

The negative control was a fragment of skin that had not been submerged in the bacterial suspension, and positive controls - fragments submerged in suspensions of appropriate studied strains, but not exposed to the action of dipping agents. After sonication, decimal dilutions were prepared and $0.1 \mathrm{ml}$ of each one was inoculated on the appropriate culture medium. After incubation $\left(37^{\circ} \mathrm{C} ; 24 \mathrm{~h}\right)$, grown bacterial colonies were counted (Fig. 1). For each strain the experiment was conducted in three replications.

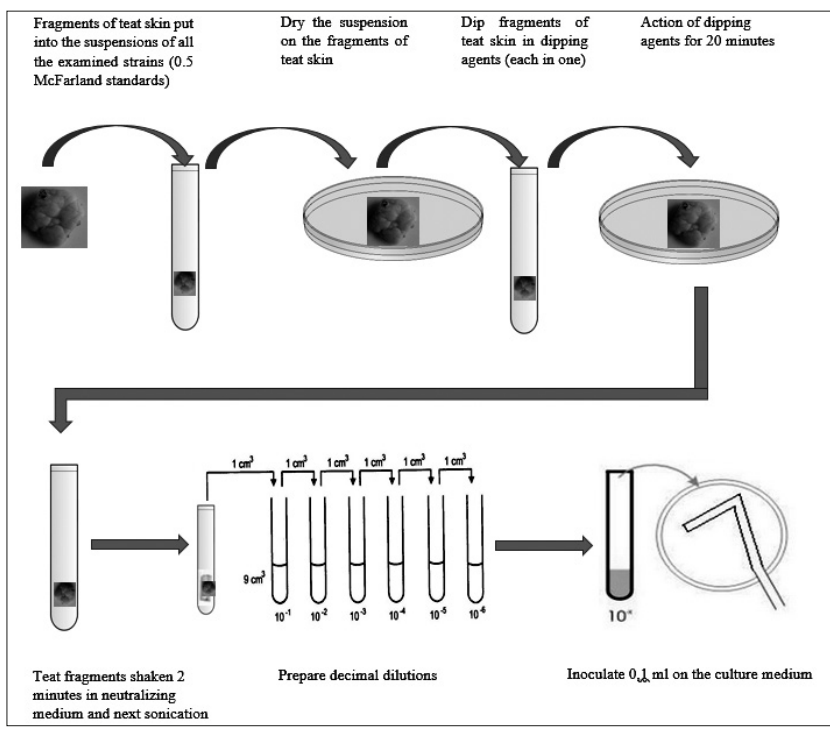

Figure 1. Scheme of the evaluation procedure of dipping agents effectiveness

Statistical analysis. The obtained results were presented per $1 \mathrm{~cm}^{2}$ of teat skin area. The mean values and standard deviation for the particular strain and for a particular species were calculated. Statistical analysis was carried out and the significance of differences between the number of bacteria re-isolated from fragments of teat skin, depending on the species and applied dipping agents, was checked using the post-hoc Bonferroni test at the significance level $\alpha \leq 0.05$. Also, the percentage reduction rate $(\mathrm{R})$ in the number of bacteria compared to the positive control was determined, according to the equation:

$$
R=\frac{K(+)-A}{K(+)} \times 100
$$

where $\mathrm{K}(+)$ = the number of bacteria in the control sample for a particular microbial species, and $\mathrm{A}=$ the number of bacteria of a particular species reisolated after the use of a dipping agent.

\section{RESULTS}

Evaluation of genetic similarity. All the studied strains of each species considered in the experiment differed genetically (Fig. 2). The most similar were L. monocytogenes: LMO 112 and LMO 327 strains (Dice's coefficient - 0.07) and E. coli: ECO 63 and ECO 67 (Dice's coefficient - 0.07). For the other strains, the value of Dice's coefficient ranged from $0.22-0.60$ (Fig. 2).

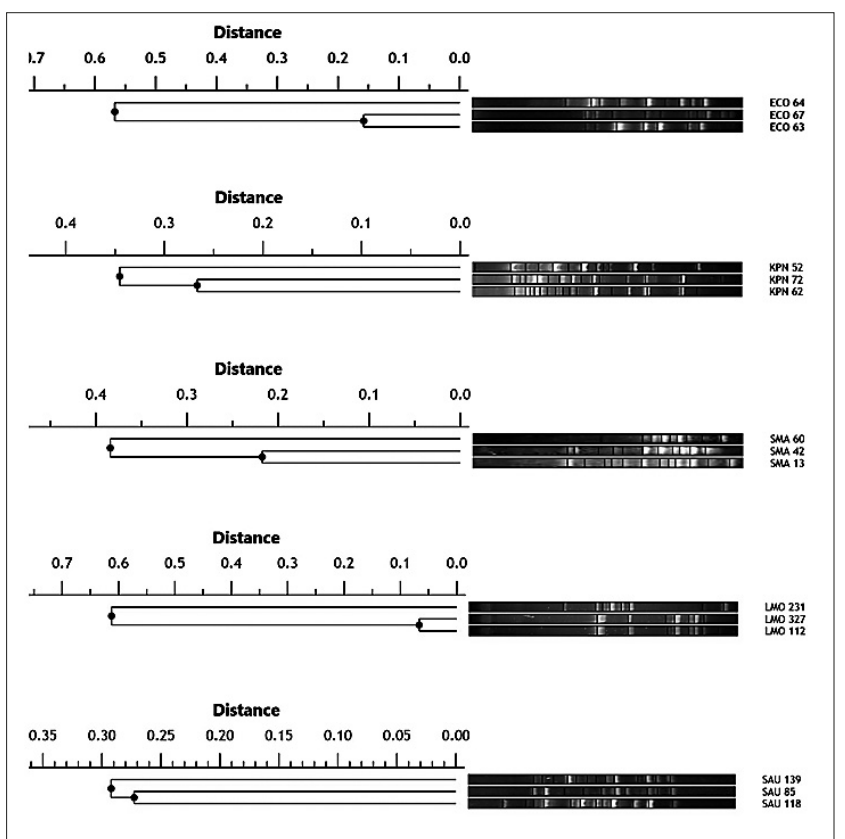

Figure 2. Assessment of genetic similarity of studied strains

Evaluation of drug susceptibility. Most isolated strains were susceptible to the studied antibiotics. All strains of Gram-negative bacilli and $S$. aureus were susceptible to aminoglycosides (gentamicin, tobramycin, amikacin, netilmicin) and tigecycline (Tab. 2 and 3). Two strains of L. monocytogenes were resistant to all the studied antibiotics, and one was susceptible to all antibiotics (Tab. 3).

Evaluation of resistance to dipping agents. The study indicated that the number of bacteria recovered from the surface of udder skin fragments not exposed to the action of dipping agents was $10^{6} \mathrm{cfu} \times \mathrm{cm}^{-2}$ for all the studied species of microorganisms vs. positive control (Tab. 4).

The obtained results showed a higher effectiveness of all tested dipping agents against the Gram-positive bacteria (Tab. 4 and 5). The mean number of Gram-negative bacteria

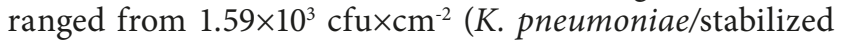
iodine) - $4.63 \times 10^{5} \mathrm{cfu} \times \mathrm{cm}^{-2}$ (S. marcescens/chlorhexidine) (Tab. 5). For Gram-positive bacteria, the mean number of bacteria isolated from udder skin ranged from $2.27 \times 10^{2}$ cfu $\times \mathrm{cm}^{-2}$ (S. aureus/stabilized iodine) $-2.45 \times 10^{4}{\mathrm{cfu} \times \mathrm{cm}^{-2}}^{-2}$ (S. aureus/iodine) (Tab. 5). Percentage reduction rate in the bacteria number varied from $99.3 \%$ (S. aureus /iodine) 99.9\% (S. aureus, L. monocytogenes/stabilized iodine) for Gram-positive bacteria and from 90.2\% (S. marcescens / 
Table 2. Susceptibility of Gram-positive bacteria to antibiotics

\begin{tabular}{|c|c|c|c|}
\hline \multirow{2}{*}{ Species } & \multicolumn{3}{|c|}{ S. aureus $(n=3)$} \\
\hline & 85 & 118 & 139 \\
\hline CXM & S & $S$ & $\mathrm{~S}$ \\
\hline GM & S & S & $\mathrm{S}$ \\
\hline AN & S & S & $S$ \\
\hline NET & S & $S$ & $\mathrm{~S}$ \\
\hline NN & S & S & $\mathrm{S}$ \\
\hline CIP & S & S & $\mathrm{S}$ \\
\hline OFX & S & S & $\mathrm{S}$ \\
\hline SXT & S & S & $S$ \\
\hline TGC & S & S & $S$ \\
\hline$E$ & S & S & $\mathrm{R}$ \\
\hline \multirow[t]{2}{*}{$\mathrm{CC}$} & $\mathrm{R}$ & S & $\mathrm{R}$ \\
\hline & \multicolumn{3}{|c|}{ L. monocytogenes $(n=3)$} \\
\hline Antibiotics $\quad$ Strain number & 112 & 231 & 372 \\
\hline$P$ & $\mathrm{R}$ & S & $\mathrm{R}$ \\
\hline AM & $\mathrm{R}$ & S & $\mathrm{R}$ \\
\hline MEM & $\mathrm{R}$ & S & $\mathrm{R}$ \\
\hline $\mathrm{E}$ & $\mathrm{R}$ & S & $\mathrm{R}$ \\
\hline SXT & $\mathrm{R}$ & S & $\mathrm{R}$ \\
\hline
\end{tabular}

Table 3. Susceptibility of Gram-negative bacteria to antibiotics

\begin{tabular}{|c|c|c|c|c|c|c|c|c|c|}
\hline \multirow{2}{*}{$\begin{array}{l}\text { Species } \\
\text { Antibiotics }\end{array}$} & \multicolumn{3}{|c|}{ E. coli $(\mathrm{n}=3)$} & \multicolumn{3}{|c|}{$\begin{array}{l}\text { K. pneumoniae } \\
(\mathrm{n}=3)\end{array}$} & \multicolumn{3}{|c|}{$\begin{array}{c}\text { S. marcescens } \\
(\mathrm{n}=3)\end{array}$} \\
\hline & 63 & 64 & 67 & 52 & 62 & 72 & 13 & 42 & 60 \\
\hline CXM & $S$ & $S$ & $S$ & $S$ & $S$ & $S$ & $S$ & $S$ & $S$ \\
\hline GM & $S$ & $S$ & $S$ & $S$ & $S$ & $S$ & $S$ & $\mathrm{~S}$ & S \\
\hline AN & $S$ & $S$ & $S$ & $S$ & $S$ & $S$ & $S$ & $S$ & S \\
\hline NET & $S$ & $\mathrm{~S}$ & $\mathrm{~S}$ & $\mathrm{~S}$ & $\mathrm{~s}$ & $\mathrm{~S}$ & $\mathrm{~S}$ & $S$ & $\mathrm{~S}$ \\
\hline $\mathrm{NN}$ & $S$ & $S$ & $\mathrm{~S}$ & $\mathrm{~S}$ & $S$ & $S$ & $S$ & $S$ & $\mathrm{~S}$ \\
\hline $\mathrm{CIP}$ & $\mathrm{R}$ & $S$ & $\mathrm{R}$ & 1 & $S$ & $S$ & $\mathrm{~S}$ & $\mathrm{~S}$ & $\mathrm{~S}$ \\
\hline OFX & $\mathrm{R}$ & $\mathrm{S}$ & $\mathrm{R}$ & $\mathrm{S}$ & $S$ & $S$ & $\mathrm{~S}$ & $\mathrm{~S}$ & $\mathrm{~S}$ \\
\hline SXT & $\mathrm{S}$ & $\mathrm{S}$ & $\mathrm{R}$ & $\mathrm{S}$ & $\mathrm{S}$ & $\mathrm{S}$ & $\mathrm{S}$ & $\mathrm{S}$ & $\mathrm{S}$ \\
\hline TGC & $S$ & $\mathrm{~S}$ & $\mathrm{~S}$ & $\mathrm{~S}$ & $S$ & $S$ & $S$ & $S$ & $\mathrm{~S}$ \\
\hline
\end{tabular}

chlorhexidine) - 99.9\% (K. pneumoniae, S. marcescens / stabilized iodine) for Gram-negative bacteria (Tab. 5). Chlorhexidine was characterized by the lowest effectiveness of all the tested agents against Gram-negative bacteria. The number of Gram-negative bacteria re-isolated after the application of chlorhexidine ranged from $1.49 \times 10^{5}$ cfu $\times \mathrm{cm}^{-2}$ (E. coli) $-4.63 \times 10^{5} \mathrm{cfu} \times \mathrm{cm}^{-2}$ (S. marcecens), and the percentage reduction in bacteria amounting to 90.15 - 97.47\%, respectively (Tab. 5). The number of recovered Gram-positive bacteria ranged from $6.05 \times 10^{2} \mathrm{cfu} \times \mathrm{cm}^{-2}$ (L. monocytogenes) $-9.95 \times 10^{3} \mathrm{cfu} \times \mathrm{cm}^{-2}$ (S. aureus) (the percentage reduction rate - 99.97 - 99.98\%) (Tab. 5). These data showed that chlorhexidine was statistically significantly more effective against Gram-positive bacteria (Tab. 5). Iodine was the least effective dipping agent against Gram-positive bacteria $\left(1.57 \times 10^{4} \mathrm{cfu} \times \mathrm{cm}^{-2}\right.$ for L. monocytogenes $-2.45 \times 10^{4}$ cfu $\times \mathrm{cm}^{-2}$ for S. aureus) (Tab. 5).

Stabilized iodine proved to be the most effective dipping agent against all the tested bacteria. The number of bacteria recovered from fragments of udder skin after the application of this agent ranged from $2.27 \times 10^{2} \mathrm{cfu} \times \mathrm{cm}^{-2}(S$. aureus) $1.25 \times 10^{4} \mathrm{cfu} \times \mathrm{cm}^{-2}$ (S. marcescens.) (Tab. 5). It was shown that $L$. monocytogenes was the most susceptible to all tested dipping preparations (99.6 - 99.9\%) (Tab. 5).

\section{DISCUSSION}

Gram-positive bacteria, such as $S$. aureus and L. monocytogenes, and Gram-negative bacteria E. coli, $K$. pneumoniae and S. marcescens, have been isolated from cow's milk in many countries [17, 28].

In the presented study, most isolates were susceptible to the used antibiotics. Similarly, in Sweden, strains of S. aureus, $E$. coli and K. pneumoniae isolated from milk showed susceptibility to the used antibiotics (among others, to gentamicin, ciprofloxacin, trimethoprim-sulfamethoxazole) $[8,29]$. In Japan, S. marcescens strains isolated from milk were most often resistant to cefuroxime (100\%), ampicillin (98.2\%) and trimethoprim-sulfamethoxazole (96.6\%) [15]. Most (98.3\%) strains of S. marcescens were susceptible to amikacin, and all to gentamicin and ciprofloxacin [15]. In the current study, two isolates of L. monocytogenes were resistant, and one susceptible to all the studied antibiotics. In Ireland, all L. monocytogenes strains isolated from fresh cow's milk were susceptible to antibiotics used in the study, including ampicillin, gentamicin and chloramphenicol [18]. In contrast, in Iran, most (98.2\%) strains of Listeria spp. isolated from cow's milk and dairy products showed resistance to at least one antibiotic applied in the study [30]. In the study by [31], $71.4 \%$ strains of L. monocytogenes isolated from milk were multidrug resistant.

Post-milking teat disinfection is regarded as one of the most effective methods for reducing the number of cases of mastitis in a herd [32]. The National Mastitis Council (NMC) has developed a list of studies evaluating the effectiveness of various agents for udder disinfection [33] in which preparations containing iodine and chlorhexidine are frequently described. In the presented study, chlorhexidine showed a higher effectiveness against Gram-positive bacteria. Boddie et al. [34] and Best et al. [35] also showed a high effectiveness of chlorhexidine against $S$. aureus and L. monocytogenes.

In the current study, iodine was the least effective dipping agent against Gram-positive bacteria. By contrast, stabilized iodine was the most effective dipping agent against all examined bacteria, because the reduction rate in the number of bacteria ranged from $99.80 \%$ (E. coli) 99.99\% (S. aureus, L. monocytogenes). A high effectiveness of preparations based on iodine at different concentrations has been described by Pelletier et al. [36]. The present study showed that $L$. monocytogenes was the microorganism most susceptible to the applied dipping preparations: the reduction rate in the number of bacteria ranged from $99.6 \%$ (iodine) 
Table 4. Number of bacteria isolated from fragments of teat skin after the use of dipping agent

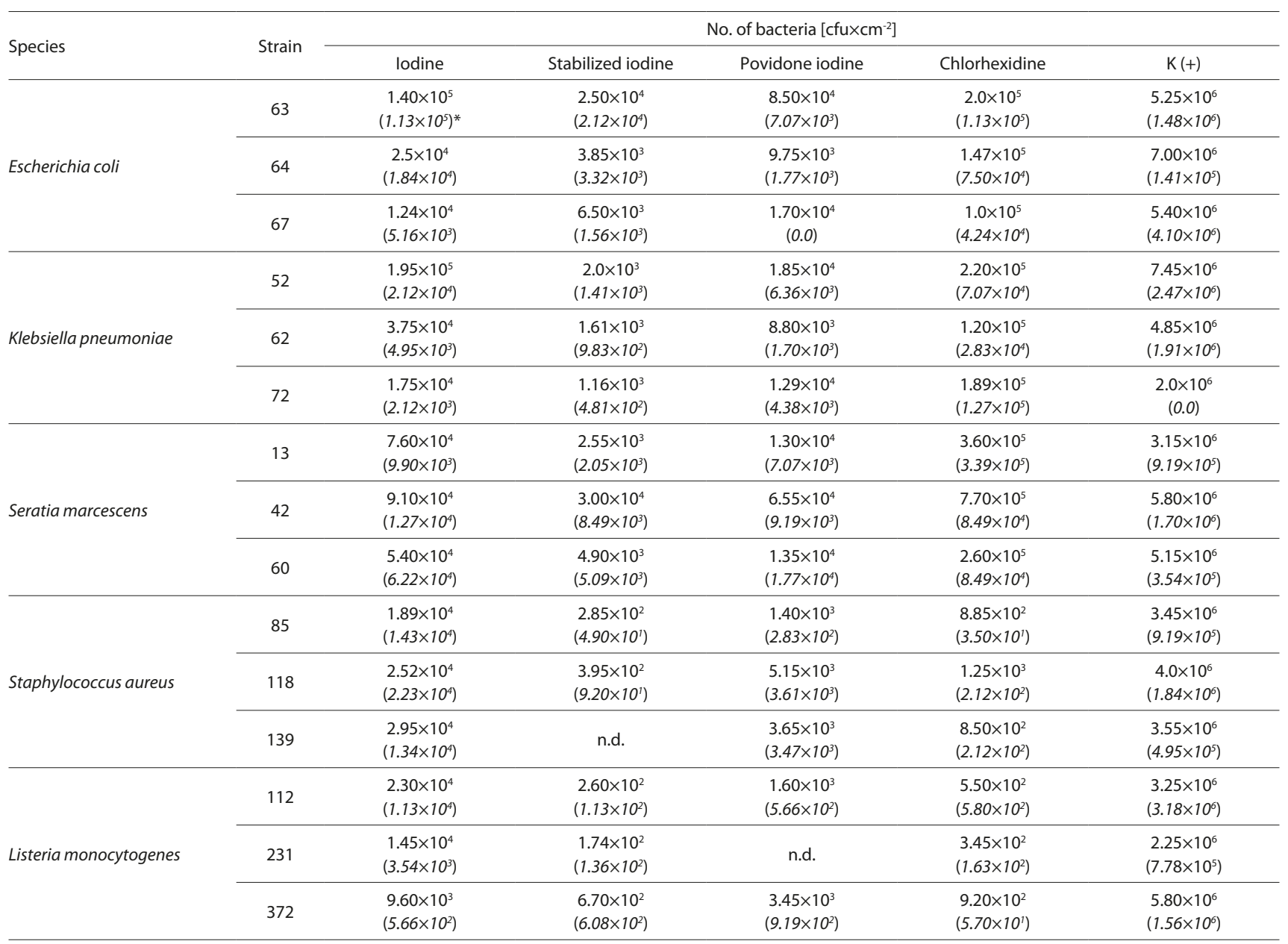

n.d. - not detected

*-standard deviation

Table 5. Statistical significance of differences in the number of recovered bacteria and percentage reduction rate in the bacteria number, according to bacteria and type of dipping agent

\begin{tabular}{|c|c|c|c|c|c|c|c|c|c|}
\hline \multirow{3}{*}{ Species } & \multicolumn{9}{|c|}{ Type of dipping agent } \\
\hline & \multicolumn{2}{|c|}{ lodine } & \multicolumn{2}{|c|}{ Stabilized iodine } & \multicolumn{2}{|c|}{ Povidone iodine } & \multicolumn{2}{|c|}{ Chlorhexidine } & \multirow{2}{*}{$\begin{array}{c}\mathrm{K}(+) \\
\begin{array}{c}\text { No. of bacteria } \\
{\left[\mathrm{cfu} \times \mathrm{cm}^{-2}\right]}\end{array}\end{array}$} \\
\hline & $\begin{array}{l}\text { No. of bacteria } \\
\left.\text { [cfu } \times \mathrm{cm}^{-2}\right]\end{array}$ & $\begin{array}{l}\text { Reduction } \\
\text { rate [\%] }\end{array}$ & $\begin{array}{l}\text { No. of bacteria } \\
{\left[\mathrm{cfu} \times \mathrm{cm}^{-2}\right]}\end{array}$ & $\begin{array}{l}\text { Reduction } \\
\text { rate [\%] }\end{array}$ & $\begin{array}{l}\text { No. of bacteria } \\
\left.\text { [cfu } \times \mathrm{cm}^{-2}\right]\end{array}$ & $\begin{array}{l}\text { Reduction } \\
\text { rate [\%] }\end{array}$ & $\begin{array}{l}\text { No. of bacteria } \\
\left.\text { [cfu } \times \mathrm{cm}^{-2}\right]\end{array}$ & $\begin{array}{l}\text { Reduction } \\
\text { rate [\%] }\end{array}$ & \\
\hline Escherichia coli & $\begin{array}{c}5.91 \times 10^{4 f, g, h, i} \\
\left(8.12 \times 10^{4}\right)^{*}\end{array}$ & 98.99 & $\begin{array}{c}1.18 \times 10^{4} \mathrm{c}, \mathrm{d}, \mathrm{e}, \mathrm{f}, \mathrm{g} \\
\left(1.41 \times 10^{4}\right)\end{array}$ & 99.80 & $\begin{array}{c}3.72 \times 10^{4} \mathrm{e}, \mathrm{f}, \mathrm{g}, \mathrm{h}, \mathrm{i} \\
\left(3.72 \times 10^{4}\right)\end{array}$ & 99.37 & $\begin{array}{l}1.49 \times 10^{5 h, i} \\
\left(7.78 \times 10^{4}\right)\end{array}$ & 97.47 & $\begin{array}{l}5.88 \times 10^{6 j} \\
\left(2.14 \times 10^{6}\right)\end{array}$ \\
\hline $\begin{array}{l}\text { Klebsiella } \\
\text { pneumoniae }\end{array}$ & $\begin{array}{c}8.33 \times 10^{4} \mathrm{~g}, \mathrm{~h}, \mathrm{i} \\
\left(8.75 \times 10^{4}\right)\end{array}$ & 98.25 & $\begin{array}{c}1.59 \times 10^{3 \mathrm{~b}, \mathrm{c}, \mathrm{d}, \mathrm{e}} \\
\left(8.84 \times 10^{2}\right)\end{array}$ & 99.97 & $\begin{array}{c}1.34 \times 10^{4} \mathrm{de}, \mathrm{ef}, \mathrm{g}, \mathrm{h} \\
\left(5.61 \times 10^{3}\right)\end{array}$ & 99.72 & $\begin{array}{l}1.76 \times 10^{5 \mathrm{~h}, \mathrm{i}} \\
\left(8.10 \times 10^{4}\right)\end{array}$ & 96.31 & $\begin{array}{l}4.77 \times 10^{6 j} \\
\left(2.81 \times 10^{6}\right)\end{array}$ \\
\hline Seratia marcescens & $\begin{array}{c}7.37 \times 10^{4} \mathrm{~g}, \mathrm{~h}, \mathrm{i} \\
\left(3.32 \times 10^{4}\right)\end{array}$ & 98.43 & $\begin{array}{c}1.25 \times 10^{4} c_{c, d, e f, g} \\
\left(1.43 \times 10^{4}\right)\end{array}$ & 99.97 & $\begin{array}{c}3.07 \times 10^{4} \text { de,ef,g,h } \\
\left(2.86 \times 10^{4}\right)\end{array}$ & 99.35 & $\begin{array}{l}4.63 \times 10^{5 i, j} \\
\left(2.90 \times 10^{5}\right)\end{array}$ & 90.15 & $\begin{array}{l}4.70 \times 10^{6 j} \\
\left(1.51 \times 10^{6}\right)\end{array}$ \\
\hline $\begin{array}{l}\text { Staphylococcus } \\
\text { aureus }\end{array}$ & $\begin{array}{c}2.45 \times 10^{4} \mathrm{e}, \mathrm{f}, \mathrm{g}, \mathrm{h} \\
\left(1.41 \times 10^{4}\right)\end{array}$ & 99.33 & $\begin{array}{l}2.27 \times 10^{2 \mathrm{a}} \\
\left(1.88 \times 10^{2}\right)\end{array}$ & 99.99 & $\begin{array}{c}3.40 \times 10^{3 \mathrm{~b}, \mathrm{c}, \mathrm{d}, \mathrm{e}, \mathrm{f}} \\
\left(2.81 \times 10^{3}\right)\end{array}$ & 99.91 & $\begin{array}{c}9.95 \times 10^{2 b, c, d} \\
\left(2.40 \times 10^{2}\right)\end{array}$ & 99.97 & $\begin{array}{l}3.67 \times 10^{6 j} \\
\left(9.81 \times 10^{5}\right)\end{array}$ \\
\hline $\begin{array}{l}\text { Listeria } \\
\text { monocytogenes }\end{array}$ & $\begin{array}{c}1.57 \times 10^{4 \text { d de,f.g.h }} \\
\left(8.06 \times 10^{3}\right)\end{array}$ & 99.58 & $\begin{array}{l}3.68 \times 10^{2 \mathrm{a}, \mathrm{b}} \\
\left(3.69 \times 10^{2}\right)\end{array}$ & 99.99 & $\begin{array}{l}1.68 \times 10^{3 \mathrm{a}, \mathrm{b}} \\
\left(1.62 \times 10^{3}\right)\end{array}$ & 99.96 & $\begin{array}{c}6.05 \times 10^{2 a, b, c} \\
\left(3.76 \times 10^{2}\right)\end{array}$ & 99.98 & $\begin{array}{l}3.77 \times 10^{6 j} \\
\left(2.30 \times 10^{6}\right)\end{array}$ \\
\hline
\end{tabular}

$\mathrm{a}, \mathrm{b}, \mathrm{c}$-statistically significant differences (post-hoc Bonferroni test, $\mathrm{p} \leq 0.05$ ) 
- 99.9\% (stabilized iodine). Best et al. [35] described a high effectiveness of povidone iodine against L. monocytogenes. Cabeça et al. [37] reported a low effectiveness of iodine towards L. monocytogenes forming biofilm $\left(2.0 \log \mathrm{CFU} / \mathrm{cm}^{2}\right)$.

The use of effective dipping agents for maintaining hygiene of the environment and milking equipment and safe behaviour of the dair ystaff are important element of mastitis prevention in the breeding of cows. In Poland, sanitary conditions in milk production have improved in recent decades [32], although there are few studies evaluating the quality of dipping agents and the effectiveness of udder disinfection treatments.

\section{CONCLUSIONS}

The presented study shows that the percentage rate reduction in the number of bacteria after the use of selected dipping agents was very high and remained at a level above $90 \%$. Some differences in tested dipping agents biocidal effectiveness indicated that selecting the proper agent is important for milk hygiene. The results obtained may contribute to a reduction in udder infections, especially mastitis, in cows and improve the quality of milk.

\section{Acknowledgements}

The authors express their thanks the dairy cattle farms for permission to collect milk samples and udder smears, and for making available dipping agents. This research was financially supported by the Nicolaus Copernicus University with funds from the maintenance of the research potential of the Department of Microbiology DS-UPB no. 782.

\section{REFERENCES}

1. Barlow J. Mastitis therapy and antimicrobial susceptibility: a multispecies review with a focus on antibiotic treatment of mastitis in dairy cattle. J Mammary Gland Biol. 2011; 16(4): 383-407. DOI: 10.1007/s10911-011-9235-z

2. Kamal RM, Bayoumi MA. Efficacy of premilking and postmilking teat dipping as a control of subclinical mastitis in Egyptian dairy cattle. Int Food Res J. 2015; 22(3):1037-1042.

3. Angulo FJ, LeJeune JT, Rajala-Schultz PJ. Unpasteurized Milk: A Continued Public Health Threat. Clin Infect Dis. 2009; 48(1): 93-100. DOI: https://doi.org/10.1086/595007

4. Shaheen M, Tantary HA, Nabi SU. A treatise on bovine mastitis: disease and disease economics, etiological basis, risk factors, impact on human health, therapeutic management, prevention and control strategy. J Adv Dairy Res. 2016; 4: 150. DOI: 10.4172/2329-888X.1000150

5. Hogan JS, Smith KL, Todhunter DA, Schoenberger PS. Efficacy of a barrier teat dip containing $0.55 \%$ chlorhexidine for prevention of bovine mastitis. J Dairy Sci. 1995; 78(11): 2502-2506.

6. Malinowski E, Gajewski Z. Characteristics of cows mastitis caused by human foodborne pathogens. Życie Weterynaryjne. 2009; 84: 290-294 [article in Polish].

7. Zadoks RN, Fitzpatrick JL. Changing trends in mastitis. Ir Vet J. 2009; 62(suppl 4): 59-70. DOI: 10.1186/2046-0481-62-S4-S59

8. Bengtsson B, Unnerstad HE. Ekman T, Artursson K, Nilsson-Ost M, Waller KP. Antimicrobial susceptibility of udder pathogens from cases of acute clinical mastitis in dairy cows. Vet Microbiol. 2009; 136(1-2): 142-149. DOI: 10.1016/j.vetmic.2008.10.024

9. Tenhagen BA, Hansen I, Reinecke A, Heuwieser W. Prevalence of pathogensin milk samples of dairy cows with clinical mastitis and in heifers at first parturition. J Dairy Res. 2009; 76(2): 179-187. DOI: $10.1017 /$ S0022029908003786

10. Malinowski E, Lassa H, Kłossowska A, Smulski S, Markiewicz H, Kaczmarowski M. Etiological agents of dairy cows' mastitis in western part of Poland. Pol J Vet Sci. 2006; 9(3): 191-194. http://www.vetpol.
org.pl/www_old/ZW2009/ZW\%202009-04\%20\%2002.pdf (access 2017.03.01).

11. Zadoks RN, Middleton JR, McDougall S, Katholm J, Schukken YH. Molecular epidemiology of mastitis pathogens of dairy cattle and comparative relevance to humans. J Mammary Gland Biol. 2011; 16(4): 357-372. DOI: 10.1007/s10911-011-9236-y

12. Bradley AJ, Green MJ. Adaptation of Escherichia coli to the bovine mammary gland. J Clin Microbiol. 2001; 39(5): 1845-1849. DOI: 10.1128/JCM.39.5.1845-1849.2001

13. Farrokh C, Jordan K, Auvray F, Glass K, Oppegaard H, Raynaud S, Thevenot D, Condron R, De Reu K, Govaris A, Heggum K, Heyndrickx M, et al. Review of Shiga-toxin-producing Escherichia coli (STEC) and their significance in dairy production. Int J Food Microbiol. 2013; 162(2): 190-212. DOI: 10.1016/j.ijfoodmicro.2012.08.008

14. Osman KM, Hassan HM, Orabi A, Abdelhafez ATS. Phenotypic, antimicrobial susceptibility profile and virulence factors of Klebsiella pneumoniae isolated from buffalo and cow mastitic milk. Pathog Glob Health. 2014; 108(4): 191-199. DOI: 10.1179/2047773214Y.0000000141

15. Ohnishi M, Sawada T, Hirose K, Sato R, Hayashimoto M, Hata E, et al. Antimicrobial susceptibilities and bacteriological characteristics of bovine Pseudomonas aeruginosa and Serratia marcescens isolates from mastitis. Vet Microbiol. 2011; 154(1-2): 202-207. DOI: 10.1016/j. vetmic.2011.06.023

16. EFSA, ECDC. The European Union summary report on trends and sources of zoonoses, zoonotic agents and food-borne outbreaks in 2014. EFSA Journal. 2016, 13, 4329. http://ecdc.europa.eu/en/publications/ Publications/zoonoses-trends-sources-EU-summary-report-2014.pdf (access: 2016.07.08)

17. Hunt K, Drummond N, Murphy M, Butler F, Buckley J, Jordan K. A case of bovine raw milk contamination with Listeria monocytogenes. Ir Vet J. 2012; 65(1): 13. DOI: 10.1186/2046-0481-65-13.

18. Harvey J, Gilmour A. Characterization of recurrent and sporadic Listeria monocytogenes isolates from raw milk and nondairy foods by pulsed-field gel electrophoresis, monocin typing, plasmid profiling, and cadmium and antibiotic resistance determination. Appl Environ Microbiol. 2001; 67(2): 840-847. DOI: 10.1128/AEM.67.2.840847.2001

19. Bogucki M, Sawa A, Neja W. Effect of change in organization of milking on yield of cows and milk quality. Roczniki Naukowe Polskiego Towarzystwa Zootechnicznego, 2011; 7: 29-35 [article in Polish]. http://ptz.icm.edu.pl/download/2011/tom_7_1/Bogucki \% 25202935\%2520RN.pdf (access 2017.03.01)

20. Galton DM. Effects of an automatic postmilking teat dipping system on new intramammary infections and iodine in milk. J Dairy Sci. 2004; 87(1): 225-231. DOI: 10.3168/jds.S0022-0302(04)73161-6

21. Gooder RA. Review of Mastitis Control Practices. A Senior Project. the Faculty of the Dairy Science Department California Polytechnic State University, San Luis Obispo, 2014.

22. Sarkar S. Microbiological considerations: pasteurized milk. International Journal of Dairy Science. 2015; 10(5): 206-218.

23. Singh V, Kaushal S, Tyagi A, Sharma P. Screening of bacteria responsible for the spoilage of milk. J Chem Pharm Res. 2011; 3(4): 348-350.

24. Anderson M, Hinds P, Hurditt S, Miller P, McGrowder D, AlexanderLindo R. The microbial content of unexpired pasteurized milk from selected supermarkets in a developing country. Asian Pac J Trop Biomed. 2011; 1(3): 205-211. DOI: 10.1016/S2221-1691(11)60028-2

25. Vogel L, Jories G, Tviep S, Koek A, Dijkshoorn L. RAPD typing of Klebsiella pneumoniae, Klebsiella oxytoca, Serratia marcescens and Pseudomonas aeruginosa isolates using standardized reagents. Clin Microbiol Infect. 1999; 5(5): 370-276.

26. Reinoso E, Bettera S, Frigerio C, DiRenzo M, Calzolari A, Bogni, C. RAPD-PCR analysis of Staphylococcus aureus strains isolated from bovine and human hosts. Microbiol Res. 2004; 159(3): 245-255. DOI: 10.1016/j.micres.2004.04.002

27. Ozeby G, Ertas HB, Kok F. Prevalence of Listeria species in camel sausages from retail markets in Aydin province in Turkey and RAPD analysis of Listeria monocytogenes isolates. Ir Vet J. 2006; 59(6): 342344. DOI: $10.1186 / 2046-0481-59-6-342$

28. Erskine R, Cullor J, Schaellibaum M, Yancey B, Zecconi A. National mastitis council research committee report bovine mastitis pathogens and trends in resistance to antibacterial drugs. Subcommittee of the NMC Research Committee. NMC Annual Meeting Proceedings 2004. https://nmconline.org/docs/ResPaper.pdf (access: 2017.03.01).

29. Persson Y, Nyman A, Grönlund-Andersson U. Etiology and antimicrobial susceptibility of udder pathogens from cases of subclinical mastitis in dairy cows in Sweden. Acta Vet Scand. 2011; 53(1): 36. DOI: 10.1186/1751-0147-53-36 
30. Rahimi E, Ameri M, Momtaz H. Prevalence and antimicrobial resistance of Listeria species isolated from milk and dairy products in Iran. Food Control. 2010; 21(11): 1448-1452. DOI: https://doi. org/10.1016/j.foodcont.2010.03.014

31. Jamali H, Radmehr B, Thong KL. Prevalence, characterization, and antimicrobial resistance of Listeria species and Listeria monocytogenes isolates from raw milk in farm bulk tanks. Food Control. 2013; 34(1): 121-125. DOI: 10.1016/j.foodcont.2013.04.023

32. Pochodyła M. Stop Mastitom! Racjonalna higiena i dezynfekcja wymienia i strzyków w aspekcie profilaktyki mastitis. Weterynaria w Terenie. 2014; 8: 58-62. [article in Polish]

33. National Mastitis Council. Summary of peer-reviewed publications on efficacy of premilking and postmilking teat disinfectants published since 1980. 2014. http://www.nmconline. org/docs/teatbibl.pdf (access 2017.03.01).
34. Boddie RL, Watts JL, Nickerson SC. In vitro and in vivo evaluation of a 0.5\% chlorhexidine gluconate teat dip. J Am Vet Med Assoc. 1990; 196(6): 890-893.

35. Best M, Kennedy ME, Coates F. Efficacy of a variety of disinfectants against Listeria spp. Appl Environ Microbiol. 1990; 56(2): 377-380.

36. Pelletier JS, Miller D, Liang B, Capriotti JA. A. In vitro efficacy of a povidone-iodine $0.4 \%$ and dexamethasone $0.1 \%$ suspension against ocular pathogens. J Cataract Refract Surg. 2011; 37(4): 763-766. DOI: 10.1016/j.jcrs.2010.11.028.

37. Cabeça TK, Pizzolitto AC, Pizzolitto EL. Activity of disinfectants against foodborne pathogens in suspension and adhered to stainless steel surfaces. Braz J Microbiol. 2012; 43(3): 1112-1119. DOI: http:// dx.doi.org/10.1590/S1517-83822012000300038 